\title{
POZITYVUS SOCIALINIS DARBAS: NUO PROBLEMINIO MODELIO LINK ASMENS STIPRYBIŲ UGDYMO
}

\author{
Valdas Rimkus, Brigita Kreivinienè \\ Klaipedos universitetas
}

\begin{abstract}
Anotacija
Straipsnyje pletojama pozityvaus socialinio darbo teorija, išryškinant kliento stiprybes. Socialinio darbuotojo profesinè veikla apima žmonių, šeimų, bendruomenių probleminių santykių analizę, socialinių pokyčių siekį, orientavimąsi ị žmonių gyvenimo kokybès užtikrinimą. Esant pliuralistiniam socialinio darbo metodų kontekstui, ypač svarbu diegti pažeidžiamų visuomenès grupių stiprybių orientacijos modelị kasdienejje veikloje. Straipsnyje plètojama mintis, kad, nepaisant socialinio darbo adresu išsakomos kritikos, pozityvioji kryptis vis dèlto formuoja fundamentaluji komunikacijos pagrindą. Neigiami lūkesčiai, klausimai, ị problemas orientuotas požiūris keičia ir paties kliento požiūrị ị save bei aplinkinių požiūrị i jị̂, kartu atitinkamai veikia elgesị ir santykius. Sunku tikètis, kad darbuotojo ir kliento santykiai nebus pažymèti atstumo, skirtingų galimybių ir kontrolès antspaudu. Atitolimas gali ypač išryškèti socialiniam darbuotojui leidus suprasti, kad tik jis turi pakankamai žinių, kurios jam suteikia teisę įvardyti problemą ir parengti jos sprendimo planą. Taip socialinis darbuotojas skatins kliento pasyvumą. Straipsnyje pabrèžiama, nors stiprybes akcentuojantis socialinio darbo modelis pabrèžia kliento norus, svajones ir siekius, tai nereiškia, kad viskas, ko pageidauja klientas, tinka. Esminis akcentas - glaudaus socialinio darbuotojo ir kliento bendradarbiavimo bei tarpusavio priklausomybės sąveika. Pozityvios perspektyvos atveju socialinis darbuotojas vietoj sutrikimo akcentuacijos domisi konkrečiais kliento pasirinkimais ir juos analizuoja.

PAGRINDINIAI ŽODŽIAI: pozityvus socialinis darbas, stiprybių modelis.
\end{abstract}

\begin{abstract}
The article analyses theoretical development of positive social work approach via highlighted strengths of client. The professional social work compounds analysis of problematic relationships of individuals, families and communities, seek for social change and orientation towards maintenance of quality of life. Strength - oriented model is essential for its application towards vulnerable groups in pluralistic context of social work methods. It is discussed in the article that despite critics towards strength-oriented model, positive approach is fundamental basis for effective communication. Negative expectations, questions, and problem-based attitude impacts client's attitude towards self, the same it changes attitude of social network towards the client, and it affects behavior and relationships. In such a case the relationships of social worker and client to be not mentioned by distance, control and different possibilities is hardly expected. This understanding gap will be much more noticeable if social worker empowers his knowledge to name and solve the problem. Therefore, social worker influences passiveness of client. The article discusses that strength-oriented social work model does not mean fulfilling all the dreams and wishes of client as well as any willingness of client is best for this client. The most essential aspects discussed in the article is seen via close collaboration of social worker and client as well as tight both-sided interaction. Positive social work is approached towards analysis of concrete choices of client instead of accentuation of disorder.
\end{abstract}

KEY WORDS: positive social work, strengths perspective. 


\section{İvadas}

2016 m. „Tiltų“ žurnalo 1-ajame numeryje buvo išspausdintas šio straipsnio autoriu tekstas "Positive social work approach: the shift from „work" towards „social“" (Pozityvus požiūris socialiniame darbe: slinktis nuo „darbo“ link „,Socialinio“), kuriame analizuojamos teorinès pozityvaus socialinio darbo prielaidos. Straipsnyje akcentuojamas poreikis praplèsti socialinio darbo, kaip mokslinès ir praktinès veiklos, sampratą, išryškinant pozityvujji dẻmenį, kaip atsvarą dominuojančiam ị problemą orientuotam socialinio darbo modeliui. Apžvelgtos pozityviosios psichologijos ir pozityvaus socialinio darbo sąsajos, pozityvaus požiūrio socialiniame darbe aktualumas ir svarba, pristatyta keletas socialinio darbo modelių, taikančių pozityvujị požiūrị.

Šiame straipsnyje pratęsiama diskusija apie pozityvaus socialinio darbo aktualumą, išsamiau apžvelgdama viena iš pozityvaus socialinio darbo sudedamųjų dalių - asmens stiprybes pabrěžiantis socialinis darbas. Toks ir išsikeltas šio straipsnio tikslas: atskleisti asmens stiprybes pabrēžiantị socialinị darbą, kaip svarbų pozityvaus socialinio darbo paradigmos komponentą. Tiek šis, tiek ankstesnis straipsnis yra greitu metu pasirodysiančios autorių monografijos apie pozityvujji socialinį darbą dalys.

\section{Asmens stiprybes pabrèžiančio socialinio darbo principai}

Stiprybes pabrèžiantis socialinio darbo modelis atsirado JAV, kaip atsakas $i$ profesijos persisotinimą asmens problemas, trūkumus, sutrikimus ir patologijas išryškinančiais diskursais (Healy, 2014, p. 165). Vienas didžiausių įnašų, įtvirtinant stiprybes akcentuojantị socialinio darbo modelį, priklauso Kanzaso universiteto (JAV) profesoriui Dennis'ui Saleebey’ui. Šị modeli jis apibūdina kaip atstovaujantị svarbiausiają - gerają - socialinio darbo pusę ir atskleidžiantị neišmatuojamas vilties galimybes bei iškeliantị sèkmę virš nesėkmès, sveikatą virš ligos, išteklius virš trūkumų. Stiprybių modelis akcentuoja kliento situacijos ir vidinių galių pažinimą, dialogo ir bendradarbiavimo svarbą tiek bendruomenėje, tiek tarp darbuotojo ir kliento. Savo knygoje „Stiprybes akcentuojantis požiūris socialinio darbo praktikoje" ("The strengths perspective in social work practice", 2013) D. Saleebey'us teigia, kad klientų problemas ir trūkumus pabrěžiančios frazès bei simboliai sukuria neigiamą lūkesčių lauką, neigiamą požiūrị i kliento aplinką bei jo galimybes atitikti aplinkos reikalavimus. Neigiami lūkesčiai laikui bègant keičia individo požiūrị ị save, aplinkinių požiūrị i j jị, kartu ir jo elgesị bei santykius. Tokiu atveju sunku tiketis, kad darbuotojo ir kliento santykiai nebus 
pažymèti atstumo, skirtingų galimybių ir kontrolès antspaudu. Atitolimas, pasak autoriaus, ypač išryškejja, jei darbuotojas leidžia suprasti, kad tik jis turi pakankamai žinių, kurios suteikia jam teisę ịvardyti problemą ir parengti jos sprendimo planą.

Kliento stiprybes akcentuojanti socialinio darbo praktika reiškia paradigmos pokytị. Ji apima ne tik stiprybių aspekto išryškinimą ịprastoje socialinio darbo veikloje, bet pasaulèžiūros, mąstymo ir kalbos pokyčius. Stiprybès - tai ne tik viena iš socialinio darbo vertybių, bet kitoks mąstymas apie socialinị darbą. Tai posūkis nuo problemos matymo link jos ịvertinimo, kaip klientas sugebejo išlikti, nepaisant patiriamos kančios ir sunkumų. Ne vienas tyrimas atskleide, kad skirtumai tarp socialinių darbuotojų taikomų intervencijos metodų yra nereikšmingi, svarbiausias dalykas, lemiantis geresnius rezultatus, yra socialinio darbuotojo ir kliento tarpusavio ryšio užmezgimas, vilties klientui ịkvėpimas, pokyčių galimybių sudarymas. Todẻl nėra visiškai teisinga manyti, kad socialinis darbas - tai, nustačius kliento „diagnozę“, parinkti šios diagnozès atveju rekomenduojamus gydymo būdus (socialinio darbo metodus), nes tokiu atveju nuvertinamas kliento ir situacijos išskirtinumas, tuo tarpu stiprybes akcentuojantis požiūris būtent ir pabrèžia kliento situacijos sudètingumą bei individualumą.

Nors stiprybes akcentuojantis socialinio darbo modelis pabrěžia kliento norus, svajones ir siekius, jis nereiškia, kad viskas, ko pageidauja klientas, tinka. Čia akcentuotina glaudaus bendradarbiavimo ir tarpusavio priklausomybės svarba. Norai, trukdantys bendradarbiauti, yra žalingi klientui ar aplinkiniams ir neturètų būti tenkinami. Pagalba kreipiama ị pilietiškumo, susieties, išteklių prieinamumo, lygių galimybių, asmeninès autonomijos, socialinès atsakomybès jausmo stiprinimą. Socialiniams darbuotojams svarbu suprasti, kodèl klientas kažką konkrečiai renkasi, o ne aiškintis, kaip konkretus pasirinkimas susijęs su patologija ar sutrikimu. Kiekvienas sprendimas neišvengiamai susijęs su socialine aplinka, kontekstu, kuriame veikia ịvairūs socialiniai, psichologiniai, ekonominiai, kultūriniai veiksniai. Svarbu suprasti ir tai, kad stiprybes pabrěžiantis modelis nėra išskirtinai orientuotas tik ị teigiamus dalykus ar vengiantis neigiamus dalykus atskleidžiančių faktų. Matyti problemą yra svarbu, tačiau stiprybes pabrěžianti pagalba siūlo kitokị, gerokai pozityvesnį šiu problemų sprendimo būdą, todẻl ji ir pristatoma kaip pozityvaus socialinio darbo sudedamoji dalis.

D. Saleebey'us skiria 6 svarbiausius stiprybes pabrèžiančio socialinio darbo modelio principus. Jie pateikiami 1 paveiksle ir pristatomi išsamiau. 


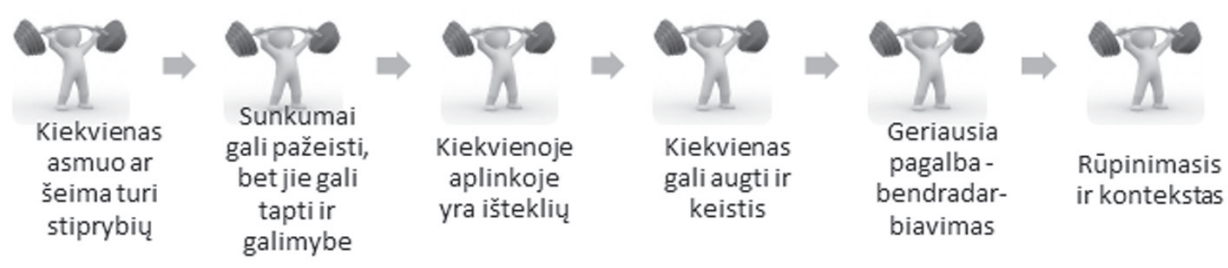

1 pav. Asmens stiprybes pabrèžiančio socialinio darbo principai

(Saleebey, 2013, p. 17-21)

Taikant stiprybes pabrèžiantị modelị, pagrindinis akcentas teikiant pagalbą yra paties kliento norai, pomėgiai, troškimai, viltys, siekiai, žinios ir gebejjimai, o ne diagnoze, simptomai ar problemos, kurias nustato kiti. Kartais sunku pripažinti, kad kiekvienas, kuriam reikia pagalbos, turi pakankamai ištekliu ir, greičiausiai, informacijos apie tai, kas vyksta jo aplinkoje. Stiprybes akcentuojantis modelis pirmiausia skatina išryškinti šiuos išteklius ir suprasti jų teikiamas galimybes sprendžiant kliento problemas.

Problemas pabrěžiantis požiūris šiandien labai ịsigalëjęs, todèl dažnai jis lemia nusivylimą, pesimizmą, aukos mąstyseną. Pavyzdžiui, smurtą patyrę asmenys, ypač vaikystèje, laikomi nukentèjusiaisiais, tai užgožia visus jų privalumus ar galimybes išgyti. Vaikai yra aktyvūs, besivystantys asmenys, galintys ịveikti sunkumus, igyti reikiamu igūdžiu ar gebejjimu. Jie kenčia, lieka randai, tačiau jie gali sẻkmingai gyventi toliau. Tai gali tapti išgyvenusiojo orumu ir išdidumu, sukelti pasitenkinimo jausmą, kad, nepaisant sunkumų, išgyveno, atsitiesė, nepalūžo. Čia ypač svarbus dvasingumas, dvasinè stiprybè.

Stiprios bendruomenès naudoja visus įmanomus bendruomenès narių išteklius. Neformalios sistemos, šeimos, bendraamžiu grupès - visa tai gali padèti įtraukti bendruomenès narius. Itraukiančios bendruomenès sudaro galimybes dalyvauti ir prisidèti prie bendros gerovès. Net ir skurdžiausiai atrodančioje bendruomenèje galima atskleisti nemažai išteklių. Visada atsiras asmenų, grupių ar institucijų, kurios gali kažką duoti, kažkuo prisidèti. Šie ištekliai dažniausia slypi už socialinès paramos sistemos ribų, jie nėra sutelkti ar tikslingai paskirstyti.

Kiekvienas žmogus turi vidiniu jègu mokytis, augti ir keistis. Jis turi teisę bandyti ir klysti. Lengva pakliūti ị požiūrio spąstus, kad diagnozė ar socialinès sąlygos riboja kliento galimybę keistis ir augti. Kartais kliento bylos peržiūrẻjimas sukelia panašių minčių, tačiau ne visada galima numatyti, kaip pakryps jo gyvenimas ateityje. Klientams mažiau pakenksime pervertinę jų galimybes, nei jas nuvertinę.

Tikra pagalba yra ta, kai siekiama abipusio sutarimo ir bendradarbiavimo, galios drauge su kitu, o ne galios kito atžvilgiu. Eksperto vaidmens prisiëmimas nèra geriausias išeities taškas pradedant pagalbos teikimo procesą. Stiprybes daug 
lengviau pavyksta atskleisti konsultantui ar bendradarbiui, o ne dominuojančiam visažiniui ekspertui. Dažnai pasitaiko, kad socialinio darbuotojo ar kitų specialistų siūlomas veiksmų planas vadinamas „pagalba ar intervencija“, o kliento siūlomas sprendimo būdas - „manipuliavimu“. Būtent klientas, o ne socialinis darbuotojas ilgą laiką gyveno konkrečioje socialinėje aplinkoje, kur jam kilo konkrečios problemos, todèl sukaupé apie tai nemažai žinių ir patirties. Klientų žinių ir nuomonės nuvertinimas, lyginant su savosiomis, yra dažna socialinio darbuotojo klaida. Juo labiau kad bendradarbiavimas padeda išvengti ir kitų galimų klaidų: paternalizmo, aukos kaltinimo ar jos sukūrimo.

Rūpesnis būtinas kiekvienam iš mūsų. Šeimos rūpinasi savo nariais, globėjai rūpinasi globotiniais ir pan. Rūpinimasis silpnesniaisiais yra kertinis demokratijos akmuo. Socialinis darbas iš esmès reiškia rūpinimąsi. Stiprybes akcentuojantis modelis - tai pat. Abu jie pabrèžia vilties teikiamas galimybes. Vilties, kuri reiškiasi per socialinius santykius šeimoje, bendruomeneje, kultūroje ar šalyje (stiprybių modelio principų apžvalga parengta remiantis Saleebey, 2013, p. 17-21).

\section{Kas gali tapti asmens stiprybėmis?}

Gyvenimiška išmintis siūlo neišgyventi dèl to, ko negalime pakeisti, ir verčiau dèmesį nukreipti ị tai, ką pakeisti galime. Kitaip tariant, tai yra siūlymas ieškoti mūsų stipriųų pusių, gebejjimų ir talentų. M. Seligman'o žodžiais tariant, stiprybių ir dorybių išnykimas iš tradicinès psichologijos dèmesio lauko paskatino jị imtis misijos sugrąžinti šiems bruožams jų vertą vietą psichologijos moksle. Todèl charakterio dorybès ir stiprybès tapo vienos svarbiausių pozityviosios psichologijos sąvoku (Saleebey, 2013, p. 2).

Analogiškos idejjos vis garsiau aptariamos ir šiandieninio socialinio darbo diskurse. Pasak D. Saleebey'aus, mes gyvename didesnio dèmesio visokeriopoms rizikoms laikotarpiu. Daugybè verslo įmonių, kitų institucijų (farmacijos, draudimo, žiniasklaidos ir pan.) pelnosi įtikinédamos, kad mums gresia ịvairios bẻdos ir nelaimès (Saleebey, 2013, p. 2). Socialinis darbas, deja, nèra išimtis, nes didžiausią dèmesị skiria kliento problemų, patologijų ir potencialių grėsmių identifikavimui. Todèl D. Saleebey'us siūlo ieškoti kliento stiprybių, gebejjimų ir kompetencijų, juolab kad toks požiūris turi daugiau galimybių klientą motyvuoti pokyčiams (Ten pat, p. 1).

Kas gi yra asmens stiprybės ir dorybės? Pasak M. Seligman'o, stiprybė - tai dorybės išsiugdymo priemonè (Seligman, 2002, p. 133). Ji apibréžiama kaip emocinė ir dvasinè savybė, padedanti išgyventi sudètingas ir stresines situacijas; teigiamas, naudingas ir pageidautinas asmens bruožas; asmuo ar objektas, tampantis emocinio ar dvasinio palaikymo ištekliumi. Stiprybė yra vertinga pati savaime, ji skatinama bendrame kultūros kontekste, laikoma teigiamu elgesio pavyzdžiu ir yra 
universali (Seligman, 2002, p. 137-139; Oxford living dictionaries, 2017). Dorybė savo ruožtu - tai aukštus moralès standartus atitinkantis elgesys; moralus, pageidautinas asmenybės bruožas (Oxford living dictionaries, 2017).

Būtina pabrèžti, kad dorybès, yra dinamiškos ir labai priklauso nuo socialinès aplinkos bei kultūrinio konteksto. Šiandieniniame Vakarų pasaulyje pripažįstamos šios dorybės - savo vertingumo pajautimas, savarankiškumas, individualumas, konkurencingumas - vargu ar būtų tokiomis laikomos prieš kelis šimtmečius, beje, ne visos jos traktuojamos kaip dorybès už vakarietiško pasaulio ribų. Todèl M. Seligman'as (2002, p. 133) pabandè sudaryti universalių dorybių, pripažįstamų daugelio didžiųų religijų ir kultūrų, sąrašą. Su kolegomis peržiūrējęs apie 200 šaltinių, aprèpiančių maždaug 3 tūkstančių metų laikotarpị, padarė išvadą, kad juose atsikartoja šios šešios dorybès: 1) išmintis ir žinojimas; 2) dvasios tvirtumas; 3) gebejjimas mylèti ir žmogiškumas; 4) teisingumas; 5) saikingumas; 6) dvasingumas.

Vis dèlto šios dorybès yra gana abstrakčios, platų turinị apimančios sąvokos. Todèl svarbu panagrinèti konkretesnius dalykus, galimybes šias dorybes išsiugdyti, t. y. aptarti asmens stiprybes.

ASMENS STIPRYBĖS

Asmens bruožai ir savybės

Aplinkos

ištekliai

IŠMINTIS IR ŽINOJIMAS

1) smalsumas, domèjimasis;

2) pažinimo džiaugsmas;

3) kritinis mąstymas, platus požiūris;

4) išradingumas, savitumas, sumanumas;

5) socialinis, asmeninis ir emocinis intelektas;

6) konteksto, visumos suvokimas

\section{DVASINGUMAS}

1) grožio, meistriškumo supratimas; 2) dèkingumas;

3) viltis, optimizmas, orientacija $i$ ateiti;

4) dvasingumas, tikejjimas, religingumas;

5) gailestingumas, atlaidumas;

6) žaismingumas, humoras;

7) entuziazmas, gyvybingumas

\section{DVASIOS TVIRTUMAS}

1) narsumas, drąsa;

2) ištvermingumas, darbštumas, stropumas;

3) sąžiningumas, principingumas, nuoširdumas
TEISINGUMAS

1) pareigingumas, lojalumas, pilietiškumas

2) dorumas,

nešališkumas;

3) lyderystè, gebėjimas vesti kitus

1) gyvenimiška patirtis;

2) kultūrinès ar asmeninès istorijos ir tradicijos; 3) fiziniai, tarpasmeniniai ir instituciniai bendruomenès ištekliai 
M. Seligman'as šešių dorybių pagrindu išskyrẻ dvidešimt keturias stiprybes, kurios padeda išsiugdyti atitinkamas dorybes. Jo požiūriu, stiprybės pirmiausia yra asmens bruožai ir savybės. Tačiau, remiantis aukščiau pateiktu apibrěžimu, stiprybe gali tapti ir asmuo, objektas ar kažkas kita, ką suvokiame kaip palaikymo išteklių. Šiuo atveju ị pagalbą ateina D. Saleebey'us, kuris pateikia galbūt ne tokị detalų, tačiau platesnị asmens stiprybių sąrašą. Abiejų autorių požiūriai sudèti ị 2 paveikslą. „Asmens bruožų ir savybių“ grafoje nurodytos universalios dorybės ir jas išsiugdyti padedančios stiprybès. „Aplinkos išteklių“ grafoje išvardyti išoriniai veiksniai, kurie gali tapti mūsų stiprybėmis.

\section{Kliento stiprybès socialinio darbo praktikoje}

Socialinis darbas šiandien vyksta pagal nusistovejjusius, viename pirmujų lietuviškai išleistų socialinio darbo vadovèlių (L. Johnson ,Socialinio darbo praktika“) aprašytus praktikos principus: informacijos rinkimas, ịvertinimas, problemos identifikavimas, plano sudarymas, intervencija, apibendrinimas. Toks praktikos modelis pats savaime nèra ydingas, tačiau jis netiesiogiai įtvirtina dominuojančią socialinio darbuotojo - eksperto padètį ir neskatina socialinių darbuotojų pakelti akių nuo problemos ir pamatyti kitą kliento situacijos pusę. Tai kliento patirtys, stiprybès, jo gebejjimai ir ịūdžiai, t. y. tai, ką pabrèžia stiprybes akcentuojantis požiūris. Kitaip tariant, socialinis darbas tapo pernelyg orientuotas ị paslaugas (dažnai užmirštant įvertinti suteiktų paslaugų rezultatus), o ne ị asmens pokytį. Tam, kad galètume planuoti tvarius pokyčius, pirmiausi, reikia pažinti žmogaus galimybes ir stiprybes. Natūralu, kad kiekvienas turime stiprybių, tačiau kaip jas atpažinti? Dažnam iš mūsų turbūt lengviau išvardyti savo trūkumus ar ydas, o paprašyti nurodyti stiprybes mes sutrinkame, dangstomès kuklumu, nenoru girtis. Nieko nuostabaus, jei pažinti kliento stiprybes taip pat bus sunku ir tai užtruks. Tačiau, jei jų neieškosime, tai ir nerasime. Norintiesiems bendravimą su klientu pakreipti stiprybių link, K. Healy rekomenduoja vadovautis šiais principais:

- Pasikliauti viltimi, orientuotis $\underline{i}$ ateiti, siekti tvaraus kliento igalinimo. Socialinio darbo siekis - motyvuoti žmogų pokyčiams, jie ịvyks greičiau, jei klientas jaus, kad juo tikima. Juk mes greičiau apsisprendžiame imtis sunkios užduoties, jei jaučiame aplinkinių palaikymą ir pasitikèjimą. Tikejjimas ir optimizmas taip pat keičia požiūrị i klientą ir sulaiko nuo etikečių jiems klijavimo bei stereotipiško jų gebejjimų menkinimo. Toki pozityvų požiūrị socialinis darbuotojas turètų skleisti ir tarp kliento socialinio tinklo narių bei visoje bendruomenèje.

- Didžiausia dèmesị skirti gebejjimu ir sprendimu paieškai, bendruomenès aktyvinimui. Pokalbio metu turetume siekti suvaldyti savo iprotị ieškoti 
problemos ar jos priežasčių apraiškų ir orientuotis ị gebejimų, stiprybių bei išteklių identifikavimą. Pavyzdžiui, perskaičius raštą apie tai, kad paauglè mergina keletą kartų per mènesị bègo iš namų, derètų domètis ne tomis dienomis, kai ji bègo iš namų, bet tuo, kas vyko jos šeimoje ir gyvenime, kai ji iš namų nebėgo, neužmirštant atkreipti dèmesio ir ị jos socialinị tinklą. Priklausymo bendruomenei jausmas pakelia mūsų savivertę ir motyvuoja keistis, todèl socialinio tinklo aktyvinimas atskleidžiant kliento teigiamas puses gali palengvinti socialinio darbuotojo darbą. Svarbiausi pokyčių bendruomenejje veiksniai, žvelgiant iš stiprybiu perspektyvos, pateikti 3 paveiksle.

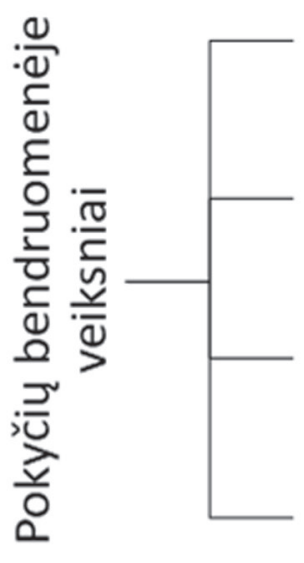

POKYTIS TURI KILTIIŠ PAČIOS BENDRUOMENĖS. Tada jis tampa "savas", o ne primestas, kyla reikšmingo indèlio, išdidumo pojūtis

POKYTIS TURI REMTIS BENDRUOMENĖSGEBĖJMAIS IRSTIPRYBÉMIS. JU galima ieškoti kiekvienamežmoguje, neformaliuose tinkluose, bendruomeninèse ir formaliose institucijose

POKYČIUS SKATINA TARPUSAVIO RYŠIAI IR BENDRADARBIAVIMAS

POKYČIAIS SIEKIAMA TVARAUS BENDRUOMENĖS AUGIMO. Tai galima pasiekti tik ieškant ištekliụ ir stiprybių pačioje bendruomenèje bei pasitelkiant juos igalinimui

3 pav. Pokyčių bendruomenèje veiksniai

(Kretzmann, McKnight, 1993, cit. Healy, 2014, p. 176-177).

- Bendradarbiauti su klientu. Pozityvus požiūris ị socialinị darbą, kaip ir stiprybes pabréžiantis modelis, akcentuoja socialinio darbuotojo ir kliento tarpusavio santykių svarbą. Susiformavęs pasitikèjimu grịstas socialinio darbuotojo ir kliento ryšys, viena vertus, tampa svarbiu ištekliumi sprendžiant problemą, kita vertus, jis yra būtina, nors ir ne vienintelè, kliento ịgalinimo sąlyga. Galiausiai šis ryšys padeda atsiverti kitokiems požiūriams, pažinti kliento dvasinị ir emocinị pasaulius, o visa tai savo ruožtu padeda ieškant sprendimų, nes sprendimų paieška yra kūrybinis procesas, kai negalima apsiriboti vienpusiu situacijos matymu (principų apžvalga parengta remiantis Healy, 2014, p. 169-173). 
Pamąstykime, kaip klostytųsi socialinio darbuotojo ir kliento bendravimas, jei pokalbis apsilankius šeimoje prasidètų ne nuo problemos ịvardijimo ar kliento bėdų paieškos, o nuo klausimų: „Kas jūsų šeimoje veikia geriausiai? Kurioje srityje jums sekasi? Ką jūs galite atlikti geriau nei kiti? Stiprybes pabrěžiančiame socialiniame darbe vadovaujamasi požiūriu, kad klientas konkrečioje situacijoje verčiasi taip, kaip tuo metu geba geriausiai (Blundo, 2013, p. 45). Todèl ị stiprybes orientuoti klausimai siekia atskleisti tuos gebejjimus ir įgūdžius, kurie padejjo žmogui iki šiol išlikti, kartu užmegzti bendradarbiavimo santykius. Stiprybes pabrèžiantis socialinio darbo modelis pateikia visą klausimų, kurie galètų būti užduodami klientui vietoj ịprastų i problemą orientuotų klausimų, sąrašą. Šie klausimai suskirstyti ị keletą sričių ir pateikti 1 lenteleje.

\section{1 lentele. Kliento stiprybes atskleidžiantys klausimai}

\begin{tabular}{|c|c|}
\hline $\begin{array}{l}\text { Ivadiniai } \\
\text { (trokštamos } \\
\text { situacijos) } \\
\text { klausimai }\end{array}$ & 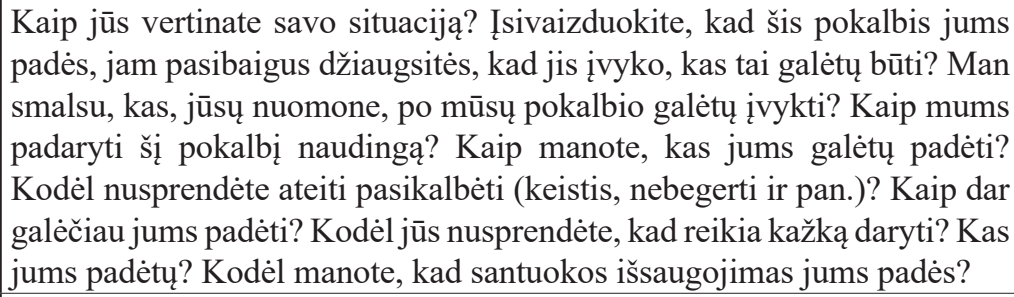 \\
\hline $\begin{array}{l}\text { Išgyvenimo, } \\
\text { išlikimo } \\
\text { klausimai }\end{array}$ & $\begin{array}{l}\text { Turint galvoje jūsų patirtus sunkumus, kaip jums pavyko išgyventi? Kas } \\
\text { jums padeda ịveikti iššūkius? Ką jūs galvojate ir jaučiate susidūręs (-usi) } \\
\text { su išbandymais ir sunkumais? Ką sužinojote apie save, ko išmokote } \\
\text { ịveikęs (-usi) sunkumus? Ar sunkumai padėjo jums išsiugdyti kokių nors } \\
\text { gebejimų ar suteikè žinių? Ar jomis naudojatès įveikdami kasdienius } \\
\text { sunkumus? }\end{array}$ \\
\hline $\begin{array}{l}\text { Palaikymo } \\
\text { klausimai }\end{array}$ & $\begin{array}{l}\text { Kurie žmonès jus geriausiai suprato, palaike ar padėjo sunkiais } \\
\text { momentais? Kuriuos iš jus supančių žmonių jūs laikote patikimais? Ką } \\
\text { šie žmonės jums duoda? Kaip juos suradote, o gal jie jus surado? Ar } \\
\text { jie ǐžvelge jumyse kažką ypatingo? Kokios organizacijos, įstaigos jums } \\
\text { labiausiai padėjo? Ar ieškodamas pagalbos galite jomis pasitikèti? }\end{array}$ \\
\hline $\begin{array}{l}\text { Klausimai dèl } \\
\text { pasiekiamų } \\
\text { tikslų, } \\
\text { galimybių }\end{array}$ & $\begin{array}{l}\text { Iš ko jūsų šeimos nariai (socialinis darbuotojas, policijos pareigūnas) } \\
\text { galėtų nuspręsti, kad jūs pasikeitète? Kaip jums tai pavyko? Jei } \\
\text { nebegersite (susirasite darbą, susitaikysite su sutuoktiniu ir pan.), kas } \\
\text { pasikeis, kaip jūs jausitès? Kas jums padejjo keistis, nors ir trumpam? Ko } \\
\text { šiandien norite iš gyvenimo? Kaip apibūdintumète savo viltis, svajones, } \\
\text { siekius? Kiek toli jums iki jų išsipildymo? Kokie jūsų gebejjimai ar } \\
\text { savybès padeda jų siekti? Ar turite ypatingų talentų ar gebejjimų? Ar } \\
\text { galite jais pasinaudoti dabartinèje gyvenimo situacijoje? Ką šiuo metu } \\
\text { galime padaryti drauge, kad padètume igyvendinti jūsų tikslus ar } \\
\text { atgaivinti gebėjimus, kurie jums padėdavo praeityje? }\end{array}$ \\
\hline
\end{tabular}




\begin{tabular}{|c|c|}
\hline $\begin{array}{l}\text { Klausimai, } \\
\text { susiję su } \\
\text { išimtimis }\end{array}$ & $\begin{array}{l}\text { Ką darėte, kad padėtumėte sau nebegerti (nebesmurtauti, užsiimti su } \\
\text { vaikais ir pan.)? Ar buvo lengva? Kuo išsiskyrè dienos, kai negėrète } \\
\text { (leidote laiką su šeima, buvote visose pamokose mokykloje ir pan.) kuo } \\
\text { jos buvo kitokios, ką darète kitaip? Kas jums padeda negerti (lankyti } \\
\text { pamokas mokykloje, būti mandagiam namuose ir pan.)? Ką darote, kai } \\
\text { kyla poreikis vėl gerti / rūkyti / grįžti prie senų ydų? Ką šeimos nariai / } \\
\text { draugė / žmona sakė, kai elgėtės kitaip? Ar anksčiau būta situacijų, kurios } \\
\text { atrodė beveik kaip jūsų pageidaujamas rezultatas? Ko nereikia keisti, } \\
\text { nes jau dabar yra tinkama? Kokius gyvenimo momentus norètumète } \\
\text { pakartoti? }\end{array}$ \\
\hline $\begin{array}{l}\text { Klausimai, } \\
\text { susiję su } \\
\text { savigarba }\end{array}$ & $\begin{array}{l}\text { Kaip manote, kodėl žmona (vyras) vis dar lieka su jumis, kas ją (jị) laiko? } \\
\text { Ar jūsų žmona (vyras) tiki, kai jai (jam) sakote tai, ką pasakojate man? } \\
\text { Papasakokite, kada pavyko ịvykdyti duotus pažadus, pasiekti užsibrěžtus } \\
\text { tikslus? Ką jums reikèjo daryti, kad sektųsi? Kaip jūs iki šiol ịveikdavote } \\
\text { sunkumus? Kas padeda jums eiti pirmyn, nepaisant nesėkmių? Kaip su } \\
\text { problemomis susidorodavote anksčiau? Ką jūs jau esate pasiekęs? Kai } \\
\text { žmonės gerai atsiliepia apie jus, ką jie dažniausia sako? Kuriais savo } \\
\text { gyvenimo poelgiais galite didžiuotis? Kokie dalykai ar žmonės jums } \\
\text { sukelia didžiausią malonumą? Ar tikite, kad galite pasiekti bent dalị to, } \\
\text { ko norite? }\end{array}$ \\
\hline $\begin{array}{l}\text { Klausimai } \\
\text { apie gyvenimo } \\
\text { prasmę }\end{array}$ & $\begin{array}{l}\text { Kokios svarbiausios idèjos ir vertybės suteikia jūsų gyvenimui prasmę, } \\
\text { kuriomis jūs labiausiai tikite ar vertinate? Kas padeda jums pajausti } \\
\text { gyvenimo prasmę? Kada ir iš kur kyla gyvenimo prasmès pojūtis } \\
\text { (patirties, kultūros, kosmoso)? Kiek šis pojūtis jums svarbus kasdieniame } \\
\text { gyvenime? }\end{array}$ \\
\hline $\begin{array}{l}\text { Klausimai apie } \\
\text { isivaizduojamą } \\
\text { (stebuklingą) } \\
\text { situaciją }\end{array}$ & 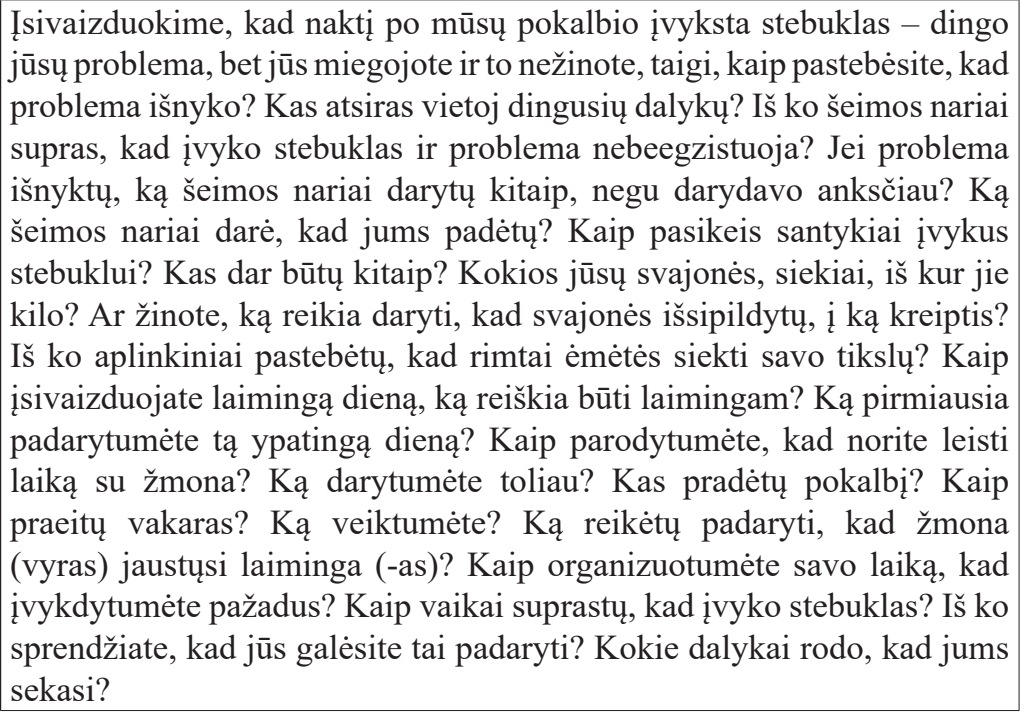 \\
\hline
\end{tabular}




\begin{tabular}{|l|l|}
\hline $\begin{array}{l}\text { Ivertinimo } \\
\text { klausimai }\end{array}$ & $\begin{array}{l}\text { Jei } 1 \text { - blogiausia situacija jūsų santuokoje, o 10 - ideali, kurioje vietoje } \\
\text { yra jūsų santuoka (gyvenimas, santykiai ir pan.) dabar? Ką darytumète, } \\
\text { kad vertinimas pradètų kilti? Ką darote, kad vertinimas nenusiristų iki } \\
\text { vieneto? Kaip manote, ką žmona (vyras) daro, kad išsaugotų savo meilę } \\
\text { jums? Ką ji (jis) žino apie jus, kad stengiasi išsaugoti santykius? Iš ko } \\
\text { pastebètumète, kad jūsų santuokos ịvertinimas ėmė kilti? }\end{array}$ \\
\hline
\end{tabular}

(remiantis De Jong, Miller, 1995; Saleebey, 2013)

Kiekvieno pokalbio pabaigoje derètų ịvertinti kliento stipriuosius bruožus, pastebètus pokalbio metu. Apibendrinimai turètų būti daromi vartojant kliento žodžius, nes tai padeda klientui jaustis svarbiam, reikšmingam, tokiam, kurio nuomonès paisoma. Vèlesniuose susitikimuose siūloma pasiteirauti, kas pasikeite ị gerą pusę, kas vyksta kitaip? Rekomenduotina šiuos klausimus dažnai kartoti, kad klientas aiškiai ir detaliai ịvardytų teigiamus pokyčius.

\section{Diskusija ir išvados}

Nepaisant vis gausėjančių mokslinių tyrimų rezultatų, pagrindžiančių stiprybes akcentuojančio socialinio darbo modelio efektyvumą, ir vis platesnio jo įsitvirtinimo socialinio darbo praktikoje, reikia atkreipti dėmesị ị šio požiūrio trūkumus, išsakomas kritines pastabas. Dažniausia literatūroje aptinkami trys stiprybes pabrěžiančio požiūrio kritikos punktai:

- politinių, sisteminių ir struktūrinių suvaržymų nuvertinimas;

- stiprybes pabrèžiančių principų ir įstatymais reglamentuotų socialinių darbuotojų funkcijų neatitikimas;

- aiškaus stiprybių identifikavimo modelio stoka (Healy, 2014; Payne, 2014).

Pirmasis punktas teigia, kad stiprybes akcentuojantis požiūris kai kuriais atvejais gali pasirodyti naivokas, ypač makroaplinkos kontekste. Asmens gebėjimai, stiprybės išties gali lemti pokyčius, tačiau dažniausia tik artimiausioje aplinkoje, mikro- ir mezolygmenyse. Vargu ar klientas yra pajègus įveikti struktūrinius ar politinius suvaržymus (Healy, 2014, p. 179). Pozityvių bruožų ir galimybių išryškinimas neabejotinai suteikia klientui pasitikejjimo, galios pojūtį, bet jam sunku pakeisti realybejje egzistuojančias, ịsisenejjusias, ilgalaikes problemas (Payne, 2014, p. 247; Healy, 2014, p. 180). Juolab kad ir socialiniai darbuotojai, spaudžiami profesiniu ịpareigojimų, dẻl laiko ir išteklių stokos nelabai turi laiko ilgesniems pokalbiams su klientu, kad galètų ieškoti jų stiprybių ar neatskleistų gebejimų. Ūmios, netikètos, trumpalaikès problemos, kaip ne vienas esame patyrę, gali mobilizuoti mūsų vidinius išteklius ir padèti įveikti bẻdą, kartu kilsteldami mūsų savivertę, pasitikejimą savimi, tačiau vargu ar panašių rezultatų galime tikètis susidūrę su ilgalaikiais ir nuo mūsų valios nelabai priklausančiais sunkumais. 
Vieną galimų atsakymų ị šias pastabas siūlo amerikiečių profesorius S. Witkin'as (2017), rekomendavęs praplèsti stiprybių modelio perspektyvą ir ị stiprybes žvelgti kaip ị tarpusavio santykių, socialinès padèties, socialinių ryšių komponentus. Jo žodžiais tariant, asmenybė yra istorinis ir kultūrinis pasiekimas, ją formuoja socialiniai santykiai ir bendravimas, todèl ir asmenybès trūkumai bei stiprybès yra ne viduje, bet išoriškai formuojamos ịvairiuose santykių kontekstuose (Witkin, 2017, p. 113). Taigi stiprybes pabrèžiantis požiūris turètų tapti ne išimtinai asmenybės bruožų paieška, bet asmens pozicionavimu bendruomenès požiūrių lauke ir pozityvių vertinimų skatinimu (Ten pat, p. 114). Juk asmenys, kurie yra laikomi nekompetentingi, neigiamai vertinami aplinkinių, marginalizuojami, vargu ar pajègs ị savo situaciją žvelgti iš stiprybių pusės. Todèl tik atsitraukimas nuo asmenybès ir dėmesys pozityviems bendruomeniniams santykiams gali padèti igyvendinti stiprybių modelị. Čia slypi atsakymas ị kritiką, kad stiprybių paieška nèra veiksminga užsitęsusių, ilgalaikių problemų atveju. Jei stiprybes laikysime pirmiausia santykių savybe, tai padès mums jas suvokti socialiniame kontekste ir matyti jų veiksmingumą. Šiame tarpusavio santykių ir konteksto svarbą pabrèžiančiame požiūryje ị stiprybes slypi ir esminis jo skirtumas nuo pozityviosios psichologijos, kuri orientuota ị individą ir jo vidines savybes (Witkin, 2017, p. 121). Taigi, nors pozityvusis socialinis darbas ịkejpimo sèmèsi iš pozityviosios psichologijos, jis neturètų būti su ja tapatinamas būtent dèl šio principinio skirtumo.

Kita vertus, diskutuojant dèl formalių, griežčiau ịstatymais reglamentuotų socialinio darbo sričių, kaip vaiko teisių apsauga, psichikos sveikatos priežiūra, nusikalstamumo prevencija, egzistuoja asmens keliamos rizikos sau ir aplinkiniams vertinimo etinė prievolè. Tai reiškia, kad išskirtinis dėmesys žmogaus stiprybėms šiuo atveju gali kelti bẻdų, nes ieškodami vieno asmens gebejjimų ir stiprybių galime neužtikrinti kito asmens saugumo (Payne, 2014, p. 246; Healy, 2014, p. 179). Pavyzdžiui, vien smurtaujančių tẻvų stipriųju pusių paieška vargu ar užtikrins jų vaikų saugumą. Tokiais atvejais socialiniai darbuotojai savo praktiką turètų labiau kreipti ị rizikos veiksnių kontrolę ir saugumo užtikrinimą, o ne ị pozityvių pusių paieškas. Juo labiau kad šiais atvejais ir patys klientai dažnai kreipiasi pagalbos, siekdami pažinti savo problemų priežastis, suprasti jų raiškos ypatumus, tad nuolatinis dèmesio perkèlimas stiprybių link gali atrodyti nepagarbus kliento siekiams ir nelabai realus ilgalaikejje problemų virtinejje (Payne, 2014, p. 245).

Vis dèlto reikètų atminti, kad stiprybes pabrezžiantis modelis neatmeta problemų egzistavimo ir nesumenkina jų reikšmès. Tiesiog siekiama, kad problemos neužgožtų stiprybių, stiprybių pažinimas taptų integralia kliento situacijos vertinimo dalimi ir taip būtų suformuotas visa apimantis kliento situacijos paveikslas, galintis padèti priimti geriausius sprendimus (Saleebey, 2013, p. 284). Juk suprantame, jeigu socialinis darbuotojas vadovausis tik pareigybiniais ịsipareigojimais ir 
profesinèmis žiniomis, nekreipdamas dèmesio ị kliento nuomonę, nesistengdamas suvokti jo situacijos, jis ne iki galo atliks savo darbą ir neturès galimybių visapusiškai įvertinti situaciją. Juo labiau kad nemotyvuotas kliento nuomonès ir prioritetų nepaisymas yra tiesiog neetiškas. Svarbu suderinti teorijos principus, socialini kontekstą ir visuomenès suteiktą socialinio darbuotojo mandatą, siekiant užtikrinti tiek asmens saugumą, tiek reikiamą pagalbą (Payne, 2014, p. 247).

Tęsiant diskusiją tenka pripažinti, kad nesukurtas aiškiai apibrēžtas, plačiau pripažintas stiprybių pažinimo, identifikavimo bei vertinimo modelis. Konkrečiai nesusitarta, kaip ir kodèl tam tikri asmens bruožai ir požiūriai priskiriami stiprybėms. K. Healy (2014, p. 180) teigimu, stiprybė yra kultūriškai determinuota sąvoka. Vienoje aplinkoje konkretus bruožas gali būti stiprybè, kitoje - priešingai. Pavyzdžiui, aktyvus savo teisių gynimas vienu atveju gali būti vertinamas kaip kliento stiprybè, tačiau kitu atveju tai gali tapti priemone savo dominuojančiai paděčiai įteisinti.

Šios kritinès diskusinès pastabos, be jokios abejonès, nesumenkina stiprybes pabrèžiančio modelio vertingumo socialinio darbo praktikoje. Jos tik dar kartą patvirtina, kad šiandien socialinis darbas yra atliekamas neapibrèžtose, daugiaprasmėse, sudètingose situacijose, kur vienpusio, šabloniško vertinimo nepakanka. Socialiniams darbuotojams nuolat tenka prisitaikyti prie aiškaus atsakymų nebuvimo, ieškoti kiekvienai konkrečiai situacijai tinkamiausio sprendimo. Ne nuostabu, kad nèra aiškaus stiprybių vertinimo modelio, vargu ar jis toks įmanomas šiandieninejje realybejje. Lygiai taip pat kaip sunkiai įmanomas ir universalus problemų vertinimo modelis. Kiekvienu atveju specialistai turi siekti pažinti konkretaus kliento situaciją ir tik jos kontekste vertinti, kas yra stiprybès, o kas ne.

Taigi apibendrinant svarbu pažymèti, kad pozityvus socialinis darbas yra neatsiejamas nuo socialinio konteksto, santykių pobūdžio, požiūriu įvairovès ir socialinès aplinkos pažinimo bei prièmimo. Jis nepateikia atsakymų ar konkrečių receptų, kaip spręsti vieną ar kitą situaciją, tačiau siūlo šios situacijos pažinimo principus, pabrěždamas idẻjų, vertybių, požiūrių ịvairovę. Pozityvumas šioje neapibrěžtoje ir kintančioje įvairovejje kyla iš siekio sukurti erdvę, kurioje skirtumai gali būti demonstruojami ir aptariami, o ne iš pastangų ịrodyti savo pozicijos teisumą, iš konkretaus geografinio, socialinio, kultūrinio konteksto pažinimo, o ne iš bandymų primesti vieną gyvenimo būdą visiems kitaip gyvenantiesiems. Vienas svarbiausių socialinio darbo tikslų - pokyčiai. Joks pokytis nebus tvarus, jei bus primestas prievarta, neatsižvelgiant ị asmens situaciją, vertybes, socialinį-kultūrinị kontekstą. Stiprybes pabrèžiantis socialinio darbo modelis, nepaisant jo trūkumų, siūlo alternatyvų požiūrị ị medikalizuotą, individualizuotą, problemomis grịstą socialinio darbo ir pagalbos žmogui diskursą. Jis suteikia erdvę vilties, galimybių, ateities ir tikèjimo leksikai bei požiūriams, o juk pasaulis yra toks, koki mes ji 
matome. Dėmesys stiprybėms yra puiki proga kurti pozityvesnị pasaulị mums patiems ir greta mūsų esantiems žmonèms.

\section{Literatūra}

Blundo, R. (2013). Learning and practicing the strengths perspective: stepping out of comfortable mind-sets. Iš: D. Saleebey (ed.). The strengths perspective in social work practice, p. 25-52. New Jersey: Pearson.

De Jong, P., Miller, S. D. (1995). How to interview for clients strengths. Social work, Vol. 40, No. 6, p. $729-736$. Prieiga internete: http://www.mcnellie.com/525/readings/dejongmiller.pdf

Healy, K. (2014) Social work theories in context: creating frameworks for practice. New York: Palgrave MacMillan.

Oxford living dictionaries. (2017). Prieiga internete: https://en.oxforddictionaries.com

Payne, M. (2014). Modern social work theory. New York: Palgrave MacMillan.

Saleebey, D. (2013). The strengths perspective in social work practice. New Jersey: Pearson.

Seligman, M. E. (2002). Authentic happiness. New York: Free press.

Witkin, S. (2017). Transforming social work. London: Palgrave.

\section{POSITIVE SOCIAL WORK: FROM PROBLEM-BASED APPROACH TOWARDS STRENGTHS PERSPECTIVE}

\section{Valdas Rimkus, Brigita Kreivinienė}

Summary

The article highlights client strengths perspective as an integral part of theoretical development of positive social work approach. Professional social work involves analysis of problematic relationships of individuals, families and communities, seeks for social change and maintenance of quality of life. Strength - oriented model is essential in its application towards vulnerable groups in pluralistic context of social work methods. The article argues that despite critics towards strengths perspective, positive approach is fundamental basis for effective communication. Negative expectations, questions, and problem-based attitudes shape client's attitude towards self, and at the same time they change attitudes of social network towards the client, affects behaviour and relationships. When problembased approach dominates it is difficult to expect that the relationships between social worker and client would not be determined by distance, control and reduced possibilities. This distance gap might increase noticeably if social worker will rely solely on his own expert knowledge and understanding in identifying and solving clients problems. Eventually, such attitudes of social worker most probably will lead to a passivity of a client.

The article concentrates its focus on strengths perspective as an alternative approach to the aforementioned model. Social work practice based on strengths 
perspective first of all implies a paradigm shift. It includes not only identifying client's strengths in everyday social work process but changes in philosophy, attitudes and means of professional language. Resting on data of several scientific research, the article argues that it's not the methods of intervention that make the most difference in social work practice, but creating the mutual relationship between social worker and client, infusing hope in a client and setting conditions for change. The essential principles of strengths perspective as defined by D. Saleebey are presented: every person and family has strengths; traumas and problems might not only hurt but also may become a source of strengths and inspiration; every environment has strengths, every person has a potential to grow and change; mutual relationship is essential in a process of help; caring for each other is a cornerstone of healthy society. Further in the text personal and contextual strengths are defined and strengths oriented questions for social work practitioners are listed. The article discusses strengths which stem from virtues as defined by M. Seligman. Strengths usually are understood as certain personal characteristics. However, authors, resting on D. Saleebey and S. Witkin, suggest broader understanding of strengths which can be seen as personal features as well as any other external, environmental factor which can be used as supporting resource.

The article discusses that strengths perspective in social work does not mean fulfilling all the dreams and wishes of a client. The most essential aspects discussed in the article are seen via close collaboration of social worker and client as well as tight both-sided interaction. Strengths perspective opens essential questions about understanding and revealing situation of client and getting to know his inner powers, stress the importance on dialogue and collaboration for all participative parties: social worker, client, and community. Positive social work is approached from the aspect of analysis of concrete choices of client instead of accentuation of disorder. Understanding the core aspects of client's choices is a challenge for social workers. This is very long and demanding process based on both-sided values, willingness, equality and respect. Each choice by no means has roots in multiple influentive factors such as social environment, context, social, psychological, economic, and cultural framework.

The critique of strengths perspective is also discussed in the article stating that sometimes strength-based approach is wrongly perceived as uniquely orientated towards positive aspects and neglecting negative facts. Identifying and understanding a problem is an important task in strengths-based approach, however it prioritizes the other much more positive way of finding solutions to them, therefore it is seen as an important component of positive social work. The basic focus of strengths-based approach is given to client's wishes, aspirations, expectations, 
goals, knowledge and skills but not diagnosis, symptoms or problems as defined by others.

Sometimes it can be hard to understand that everyone in need of support has enough resources and possibly enough knowledge about its situation. Therefore, strengths-based approach sets its primary goal to find and highlight these resources and bring to the light client's potential to solve problems. The article invites to think what if the first social worker - client meeting starts not from mentioning the problem but from positive questions, such as: "What works best in your family? What are the strongest sides of your participation in activities? What are you doing best? What can you do better than others?" Strengths-based approach presumes that client acts in every concrete situation the best he at the moment is capable of. Therefore, if we ask questions pointing at client's best and most successful sides we will know what skills and knowledge helped him to survive till today as well as start constructing collaborative relationships. 